\title{
Psychological and pedagogical conditions for the formation of professional and communicative competence of students of an agricultural university in the study of speech disciplines (from work experience)
}

\author{
Natalia Chernikova ${ }^{1,{ }^{*}}$, Inna Sidorova ${ }^{1}$, Natalia Melekhova ${ }^{1}$, and Alexander Fedotov ${ }^{1}$ \\ ${ }^{1}$ Michurinsk State Agrarian University, International st., 101, Michurinsk, 393760, Russia
}

\begin{abstract}
The definition of the concept of «communicative personality» is substantiated. It means the subject of speech, who is able to express his thoughts freely and competently, who knows the language norms, expressive means and stylistic resources of the literary language, who is able to create oral and written texts of different genres, to receive and analyze information from different sources, possessing communication technologies and the ability to use them effectively in professional and other communication situations. The definition of the concept of «professional ideal» is formulated. It implies the image of a highly qualified professional, which has developed in the mind of a student of a higher educational institution. The necessity of creating psychological and pedagogical conditions for the formation of professional and communicative competence of students of an agricultural university in the disciplines of the speech cycle has been proved. Among them are the following: the formation of the professional ideal of students as a personal, internal motivation for learning; a communicative-cognitive approach to the formation of a student's communicative personality; gradual formation of a communicative personality in the learning process.
\end{abstract}

\section{Introduction}

In the modern business world, employers make serious demands on graduates of higher educational institutions, including high professional competence, social maturity and activity, general cultural competence, a component of which is high speech competence. These requirements apply to specialists of all profiles who have received both humanitarian and agricultural, technical, military, medical and other education [1-3]. Formed speech competence in the modern business sphere, and therefore in the agro-industrial complex, is considered as an integral part of the professional competence of a university graduate [4-6]. In the context of a rapidly expanding and dynamically developing information and communication space, speech, in its various forms and genres, has become one of the most

*Corresponding author: chernikovanat@mail.ru 
powerful means of regulating business relations, professional activities of specialists. That is why, in the current State educational standards of higher education, the academic discipline of the speech cycle is included in the list of disciplines of the federal component. This means that this discipline in the curricula that build the educational route of students in higher educational institutions, including in agricultural universities, belongs to the mandatory part of the basic block and is part of the "Communicative» module. Currently, in the educational programs of our university, such a discipline, in accordance with the state educational standard, is «Russian language and culture of speech», before it was the training courses «Rhetoric», «Rhetoric and culture of speech», «Culture of speech and rhetoric». The name of the disciplines and partly their content vary, but they all belong to the number of functional communication courses.

The main goal of the speech discipline, which is studied by undergraduate students enrolled in educational programs at an agricultural university, is the formation of the communicative competence of the subject of the educational process.

By communicative competence, following modern specialists in the field of pedagogy, psychology, linguistics, linguodidactics, we mean the formed ability to freely select and effectively use linguistic means, taking into account the conditions for the implementation of a speech act and its participants, in accordance with the goals and sphere of communication. The formed communicative competence ultimately unites such components that characterize personality traits as communicative-psychological, communicative-linguistic and communicative-logical [7, 8].

In order to achieve this goal, the following tasks are solved in the course of the speech discipline at the agricultural university, aimed at mastering theoretical knowledge and practical skills, abilities and skills:

- formation of knowledge about language and speech, speech activity, speech communication and its structure;

- mastering the communicative qualities of speech, including correctness (normativity), purity, wealth, accuracy, consistency, expressiveness, relevance, and others);

- mastering the norms of the Russian literary language (spelling, orthoepic, lexical, grammatical, stylistic and others);

- the formation of skills for the correct construction of oral and written speech, depending on its genre, situation, sphere of communication, addressee;

- the formation of skills for creating professionally significant speech works (texts) in various forms and genres;

- the formation of the ability to adequately assess one's own speech and the speech of other participants in verbal communication, including in situations of business communication;

- mastering the ways of argumentation;

- developing public speaking skills;

- formation of the idea of speech as an effective means of regulating people's professional activity.

We have not found numerous scientific studies aimed at studying the specifics and conditions for the formation of professional and communicative competence of students of an agricultural university in domestic science. At the same time, we note the profound research of E.B. Zorina (2004), devoted to the study of the technology of forming the professional speech culture of students of the agricultural university, as well as the work of N.V. Lyubeznova, I.S. Vykhodtseva, I.V. Sadilova [9], N.K. Lotova, N.E. Prudetskaya [10], devoted to the peculiarities of the development of the speech culture of students of an agricultural university. 


\section{Material and methods}

The subject of our research is the psychological and pedagogical conditions for the formation of professional and communicative competence of students as one of the most important components of professional training of a specialist in an agricultural university.

To identify these conditions, we used the following research methods and techniques, tested by us in the process of many years of teaching speech disciplines in higher education:

- structured observation of students' speech in order to obtain objective facts that reflect the level of formation of their communicative competence;

- group and individual conversations with students, aimed at identifying the qualitative and quantitative characteristics of their speech;

- testing in order to identify the communication skills of students, their abilities and speech and thinking skills;

- psychosemantic method, allowing to identify the universal and individual characteristics of the student's communicative personality;

- methods of self-characterization and self-presentation, allowing to identify the adequacy of self-assessment of students in determining the level of formation of each of them as a communicative personality;

- socio-pedagogical examination aimed at forming a holistic view of the level of communicative competence of students of an agricultural university;

- socio-pedagogical forecasting, which allows to design probabilistic prospects for the formation of each student as a communicative personality.

\section{Results and discussion}

For the formation of professional and communicative competence of students in the educational process of an agricultural university, psychological and pedagogical conditions must be created, without which it is impossible or difficult to effectively train a specialist, in relation to whom the characterological nomination "communicative personality» is applicable.

In modern scientific research, it is customary to understand a communicative personality as a subject of speech, a native speaker who is able to express his thoughts freely and competently, fluent in linguistic norms, expressive means and stylistic resources of a literary language, able to create oral and written texts of different genres in different stylistic registers, capable to receive and analyze information from various sources, possessing communicative, including non-verbal, technologies and the ability to use them effectively in professional and other communication situations [11, 12].

Long-term experience of working with students studying in different specialties, directions and profiles in fruit and vegetable, engineering, economic, social and pedagogical institutes of the agricultural university, allowed us to identify and create the necessary psychological and pedagogical conditions for the formation of a communicative personality of a university graduate with developed professional and communicative competence. Among them are the following.

1. Formation of the professional ideal of students as a personal, internal motivation for learning. The concept of «professional ideal» means the image of a highly qualified professional that has developed in the mind of a student of a higher educational institution. The content of the professional ideal includes professionally significant values and their interpretation by the trainee. One of the components of the content of the professional ideal is high speech competence.

It is necessary to take into account the importance of forming the professional ideal of students of an agricultural university when developing curricula in all disciplines included 
in the educational route of a certain direction and profile. An important place in the formation of the professional ideal of students, as our practice shows, is taken by the speech discipline («Russian language and speech culture», «Rhetoric and speech culture», etc.).

When developing a work program for this discipline, preparing materials for conducting training sessions, we must take into account the direction, specialization, profile of students of an agricultural university. Let us show this by the example of studying spelling and orthoepy.

One of the tasks of the speech discipline, as we noted above, is mastering the norms of the literary language, including, among others, spelling and orthoepic norms.

The foundations for the formation of spelling and orthoepic literacy are laid at school in the Russian language lessons. The graduate of the school must be proficient in relative spelling and orthoepic literacy. The school does not set itself the task of forming students' absolute literacy in the field of spelling and spelling, because it is practically unattainable. Despite this, school graduates come to higher educational institutions with a considerable amount of knowledge in the field of these branches of linguistics. Therefore, the study of the norms of written and oral speech by students of an agricultural university preserves the continuity of the school curriculum, deepens and improves the knowledge acquired at the stage of secondary education in these subject areas.

The content of work on spelling in high school includes the deepening of spelling knowledge, improving the spelling skills and skills of students. Carrying out this work in a specific lesson on a specific topic, in the didactic verbal and spelling material, which is offered for practicing spelling skills, we must include words that are part of the name of the direction, profile, specialization of students of the agricultural university. We call these words «professionally oriented». Examples of such verbal material and its correspondence to the studied spelling are presented in Table 1.

Table 1. Types of spelling.

\begin{tabular}{|c|c|}
\hline Spelling & Examples of «professionally oriented» words \\
\hline $\begin{array}{l}\text { Unstressed verifiable vowels at the } \\
\text { root }\end{array}$ & $\begin{array}{l}\text { архитектура, } \\
\text { плодоовощеводство, } \\
\begin{array}{l}\text { строчтолительныный, } \\
\text { хранение, экология }\end{array}\end{array}$ \\
\hline Unverifiable vowels and consonants & $\begin{array}{l}\text { агрономия, анализ, архитектура, аудит, } \\
\text { бухгалтерский, кадастры, ландшафт, } \\
\text { проектирование, производство, кредит, } \\
\text { менеджмент, обеспечение, оборудование, } \\
\text { прочесс, сертификачия }\end{array}$ \\
\hline Letters И and Ы after Ц & $\begin{array}{l}\text { организачия, механизачия, муниципальный, } \\
\text { продукиия, сертификация, стандартизация, } \\
\text { эксплуатачия }\end{array}$ \\
\hline $\begin{array}{l}\text { Connecting vowels } \mathrm{O} \text { and } \mathrm{E} \text { in } \\
\text { compound words }\end{array}$ & $\begin{array}{lr}\text { агропочвоведение, } & \text { жизнедеятельность, } \\
\text { землеустройство, } & \text { плодоовошеводство, } \\
\text { природопользование, } & \text { садоводство, } \\
\text { сельскохозяйственный, } & \text { техносфера, } \\
\text { техносферный, } & \text { электрооборудование, } \\
\text { электротехнологии } & \\
\end{array}$ \\
\hline Hyphen in compound words & $\begin{array}{l}\text { садово-парковый, } \\
\text { технологический, экономико-правовой }\end{array}$ \\
\hline $\begin{array}{l}\text { Compound words without a } \\
\text { connecting vowel }\end{array}$ & $\begin{array}{l}\text { агроинженерия, } \\
\text { агропромыиленный, } \\
\text { биотехнология, зоотехния }\end{array}$ \\
\hline
\end{tabular}

The content of the work on orthoepy in higher education includes deepening orthoepic knowledge, improving the skills of oral speech in the aspect of correct pronunciation of 
words and correct stress setting, expansion of the so-called «orthoepic minimum». The concept of «orthoepic minimum» has entered the methodology of teaching the Russian language in secondary schools and has become relevant in the preparation of senior students for passing the Unified State Exam in Russian. The composition of the «orthoepic minimum» includes about 300 words, in which school graduates must know the correct formulation of stress.

Carrying out in the classroom work on orthoepy, as well as spelling, in the didactic verbal and orthoepic material, we necessarily include «professionally oriented» words that are part of the name of the direction, profile, specialization of students of an agricultural university. Usually these are words that cause difficulties or doubts about the correct placement of stress in them (more often) or in their pronunciation (less often). Examples of such orthoepic material are presented in Table 2.

Table 2. Words that cause difficulties in staging stress and pronunciation.

\begin{tabular}{|l|l|}
\hline $\begin{array}{l}\text { Words that cause difficulties } \\
\text { in stress setting }\end{array}$ & $\begin{array}{l}\text { агроинженерия, агрономия, зоотехния, } \\
\text { менеджмент, обеспечение, средства }\end{array}$ \\
\hline $\begin{array}{l}\text { Words that cause difficulties } \\
\text { in pronunciation }\end{array}$ & $\begin{array}{l}\text { архитектура, бухгалтерский, виноградарство, } \\
\text { плодоовочеводство, проектирование, сервис }\end{array}$ \\
\hline
\end{tabular}

Studying various disciplines within the framework of the educational program being mastered at an agricultural university, students independently supplement the list of «professionally oriented» words, including the names of educational courses, terms from the studied areas of knowledge, professional words that cause them difficulties or doubts in writing and or pronunciation. When carrying out intermediate certification, knowledge of the correct spelling and pronunciation of «professionally oriented» words is a prerequisite for mastering the discipline.

2. Communicative-cognitive approach to the formation of a student communicative personality.

The formation of a communicative personality is closely related to the cognitive abilities of a person, which are also acquired and developed in different ways and means, among which educational activity occupies an important place. To form the speech competence of a university graduate in the educational process we use a communicativecognitive approach [13], which involves the assimilation of two types of knowledge by students:

1) declarative knowledge that students receive at lectures, during independent study of scientific and educational literature from audio and video sources, etc.;

2) procedural knowledge that students receive in the process of real actions, solving practical problems, etc. Procedural knowledge is acquired using active teaching methods (educational discussion, business game, group problem solving, cluster method, project method, etc.), which contribute to the development of cognitive interest and the creative potential of the individual [14-16]. The assimilation of two types of knowledge in the study of speech discipline and the conscious possession of them determine the formation of the communicative and professional skills of students and form the basis for their further use in professional activities.

The communicative-cognitive approach is primarily associated with the ability of students to perform elementary speech-thinking operations - comparison, contrast, analysis, synthesis, generalization and others [17], which quite often cause difficulties for students. Therefore, in the lessons of the speech course, we use teaching technologies that contribute to the development and improvement of these speech-thinking operations. Constant training of cognitive actions forms the flexibility and breadth of students thinking, the ability to navigate freely in the information space, to analyze and evaluate critically texts of different styles and genres, to create independently texts, including those which are related to their 
future profession. The implementation of this approach in teaching enables the teacher to develop individual communicative and cognitive style of a future specialist.

One of the tasks of the speech discipline in an agricultural university is systematic teaching of speech genres, which presupposes the ability to create a stylistically competent text. The concept of «stylistically literate text» means a speech work that in its content and structural aspects is adequate to the goal, objectives, conditions and situation of speech communication, that is, it corresponds to a specific speech genre.

The speech genre is a very important concept in any field of communication, especially in the professional one. Therefore, students must study a variety of speech genres of business and everyday communication. At the same time we pay special attention to speech genres that will be in demand in their professional activities. For example, these are speech genres such as a business conversation, a business meeting, business negotiations, an agreement (for students of all profiles), an analysis of the economic situation, a financial report, a statistical report (for students of economic specialties), instructions, recommendations, consultations (for students of technical specialties) and others.

When teaching students speech genres, we use a communicative-cognitive approach. Thus, acquaintance with a specific speech genre is carried out not only through the acquisition of declarative knowledge in the process of describing its genre-forming characteristics, but also as a result of comparison, comparison with other speech genres. For example, students, having become acquainted with the video materials - recordings of a business conversation and business negotiations, independently identify and analyze the general and individual characteristics of these genres of business communication. Such speech-thinking operations lead to the formation of procedural knowledge in students.

3. Stage-by-stage formation of a communicative personality in the learning process.

The concept of «communicative personality» includes many characteristics associated with a person's communicative experience. Students acquire communicative experience, firstly, spontaneously: during socialization, involvement in different types and forms of communication, including in the process of studying at a higher school when mastering all academic disciplines within the framework of the educational program being mastered. Secondly, communicative experience is a value that is formed purposefully, in particular, in the lessons of a speech course.

It is practically unattainable to form a communicative personality within the framework of one discipline. At the same time, our experience of working with students of an agricultural university in teaching them the discipline of the speech cycle allows us to organize training in such a way that in the process of mastering the course, both the teacher and the student himself see the dynamics in the development of communicative personality and in the acquisition of communicative experience.

At the beginning of the course we use the methods of self-characterization and selfpresentation $[18,19]$. At one of the first lessons in our discipline, after getting acquainted with the concept of «communicative personality» and its meaningful characteristics, each student receives the task to characterize himself as a communicative personality, to assess his level of formation as a communicative personality. For this, we have developed criteria, including, for example, such as mastery of the norms of the literary language, richness of vocabulary, purity of speech (the absence of unnecessary, unnecessary words, jargon, vulgarisms, etc.), the ability to build an oral monologue and written text in accordance with specific communicative tasks, the ability to conduct a dialogue, the ability to extract information from texts of different styles and genres, mastery of public speaking skills, and others.

As a rule, the results of student introspection are overestimated. Most of them consider themselves a mature communicative person who is fluent in speech in all its forms, types and manifestations. In fact, it turns out to be completely different, which each student is 
convinced of himself, having received one of the assignments, which allow at least partially to test communication skills. Here are examples of such tasks: retell its content competently and close to the text; give a detailed answer to the question posed; reasonably prove your point of view on a specific problem; publicly speak to an audience with a prepared speech, etc.

In this regard, in the lessons of the speech course, we set ourselves the task of the gradual formation of the student communicative personality. This work is carried out according to the traditional scheme: from simple to more complex. As an example, we will demonstrate the stages of work in the study of speech genres.

At the first stage, such speech-thinking skills of students as perception, recognition, comparison, are improved. Students complete the following task:

Compare the texts. What functional style do they belong to? Indicate the genre of each text.

At the second stage, analysis and proof are connected as important speech-thinking operations. Students receive the following assignments:

1) Compare the texts. What functional style does each of them belong to? Prove your opinion by identifying the non-linguistic and linguistic features of each text.

2) Compare the texts. Define their genre. Which of these texts, in your opinion, will make it possible to achieve more effectively the set of communicative goal? How can this be explained?

The third stage involves the development of such speech-thinking skills as correlation (with a model or with requirements), substitution (bringing in line with the norm). At this stage the following tasks are relevant:

Analyze the text. What functional style does it belong to? Determine the genre of the text. Indicate speech deficiencies in the text. What, from your point of view, are they caused? Make any necessary changes to the text.

At the fourth stage, the most complex communicative and cognitive skills are practiced - structuring and construction. At this stage, students must independently create a text of a certain speech genre. For example:

1) Prepare a business text in the genre of analyzing the economic situation in modern Russia.

2) Prepare a text about the economic situation in modern Russia in the genre of a private letter addressed to a friend (relative).

This is how the formation of the communicative skills of students takes place in stages, and, consequently, the communicative personality is formed.

\section{Conclusion}

There are sufficient grounds for considering professional and communicative competence as one of the most important components of professional training of a specialist in an agricultural university. Its formation is an important educational, social, sociocultural task that meets the needs of modern society and the business world. The professional success of a graduate who has received a university education is largely determined by the extent to which he is formed as a communicative personality.

A communicative person possesses a complex of verbal and cognitive knowledge, skills, abilities and skills that allow her to feel confident in the professional sphere, to navigate freely in the modern business world, to realize her creative potential in social and professional activities, to regulate the behavior of all participants in communication, to vary communication strategies and means taking into account the dynamics of the speech situation. 


\section{References}

1. L.a Chuikina, Lingua mobilis 1(34), 62-66 (2012)

2. N. Sidorova, Philological and pedagogical aspects of liberal arts education in nonlinguistic universities of the Federal Penitentiary Service (FSIN) of Russia, 200-207 (2017)

3. T. Morozova, Eurasian Scientific Association 10-5(56), 404-406 (2019)

4. L. Filkova, Formation of student readiness for speech communication in the educational process of the university (2011)

5. T. Cherkashina, Formation of communicative leadership in the dialogue system of higher management education (2011)

6. R. Sagitova, Formation of self-educational competence of university students in the process of studying the humanities (2011)

7. T. Raspopopva, Russian language at school 5, 73-78 (2015)

8. L. Khodyakova, Russian language at school 5, 78-82 (2017)

9. N. Lyubeznova, Modern Education 2, 149-154 (2018) doi: 10.25136/24098736.2018.2.25800

10. N. Lotova, Siberian Pedagogical Journal 3, 84-88 (2018)

11. E. Chebotareva, Psychological Research 8(39), 7 (2015)

12. O. Evtushenko, Bulletin of the Volga University named after V.N. Tatishcheva 2(4), 73-80 (2016)

13. N. Isaeva, Russian language at school 1, 95-100 (2019) doi: 10.30515/0131-61412019-80-1-96-100

14. A. Murashov, Russian language at school 6, 96-102 (2011)

15. E. Senchenkova, Russian language at school 4, 68-72 (2018) doi: 10.30515/0131-61412018-79-4-68-72

16. V. Gavrilov, Pedagogical Journal of Bashkortostan 1, 127-137 (2020)

17. I. Mikhailova, Russian language at school 81(4), 94-103 (2020) doi: 10.30515/01316141-2020-81-4-94-103

18. L. Prokhorenko, Russian language at school 2, 63-68 (2018) doi: 10.30515/0131-61412018-79-2-63-68

19. I. Mishina, Russian language at school 2, 69-73 (2018) doi: 10.30515/0131-6141-201879-2-69-73 